\title{
Maria Wilczek-Krupa
}

\section{Z DALEKIEGO KRAJU}

\section{MYŚL KAROLA WOJTYEY W KADRZE I ZZA KADRU}

\author{
Najwybitniejsi kardynałowie powołali nowego \\ biskupa Rzymu. Powołali go z dalekiego kraju, \\ z dalekiego, ale jednocześnie jakże bliskiego poprzez \\ komunię w chrześcijańskiej wierze i tradycji (...). \\ Nie wiem, czy będę umiał dobrze wysłowić się \\ w waszym... naszym języku włoskim. Gdybym się \\ pomylił, to mnie poprawcie ${ }^{1}$. \\ Jan Paweł II
}

To właśnie do tego przemówienia Karola Wojtyły, wygłoszonego z balkonu Bazyliki Świętego Piotra tuż po wyborze na biskupa Rzymu, nawiązał w tytule pierwszej pełnometrażowej fabuły o Janie Pawle II Krzysztof Zanussi. Zadanie było wyjątkowo trudne - Polska u progu lat 80 . stała za żelazną kurtyną, społeczeństwo zmagało się z kryzysem, a sztuka $\mathrm{z}$ cenzurą. Filmowa biografia żyjącego papieża (prace nad scenariuszem rozpoczęły się latem 1979 roku, produkcja weszła na ekrany europejskich kin we wrześniu 1981), u progu pontyfikatu przełamującego monopol Zachodu na piastowanie najwyższej funkcji w hierarchii kościelnej, wydawała się przedsięwzięciem nie tyle karkołomnym, ile niemożliwym. „Nagle okazało się, że mamy w tym udział - mówił reżyser. - Jest coś zaskakującego w tym, jak dalece posunęła się ta uzurpacja ważności. Film tę uzurpację narusza. I w tym widzę coś pięknego"2.

${ }^{1}$ K. Wojtyła, fragment przemówienia po wyborze na papieża, www.aan.gov.pl (dostęp: 8.3.2021).

${ }^{2}$ K. Zanussi, Z dalekiego kraju, wypowiedź dla Filmowego Ruchu Ewangelizacyjnego przed emisja filmu w kościele pod wezwaniem świętego Andrzeja Boboli w Bielsku-Białej, www.pallotti.tv (dostęp: 8.3.2021). 


\section{„Jak napisać scenariusz? Nie wiem”}

Już sam tytuł polsko-brytyjsko-włoskiej produkcji jest pewnego rodzaju grą, którą Zanussi chętnie podejmuje z widzem, i której zawdzięcza dziś miano „intelektualisty polskiego kina"3. Chodziło bowiem o to, by odbiorcy zagranicznemu (niemającemu pojęcia o historii Polski) przybliżyć dzieje i realia „dalekiego kraju”, z którego pochodzi namiestnik Stolicy Piotrowej. Dalekiego, a jednocześnie przecież bliskiego, za pośrednictwem tradycji chrześcijańskiej i związków z katolicką doktryną. Tak sformułowanemu celowi miała służyć prosta, dydaktyczna i dokumentalizowana formuła utworu, która wkrótce stała się podstawowym zarzutem wobec twórców $Z$ dalekiego kraju.

Do współpracy przy swojej osiemnastej fabule Zanussi zaprosił mistrzów: za zdjęcia odpowiadał Sławomir Idziak, za muzykę - Wojciech Kilar. Największa odpowiedzialność spoczywała na twórcach scenariusza, od których reżyser oczekiwał skonstruowania wartkiej opowieści o papieżu bez... papieża. Zanussi tłumaczył: „Wobec żywego człowieka obowiązuje mnie prawo poszanowania jego prywatności, a więc nie mogę opowiadać o tym wszystkim, co jest bez wątpienia dla widza najciekawsze - o osobistych dylematach, o cierpieniu, o sukcesach i porażkach"4.

Inspiracją i kluczem do takiego zamysłu był dramat Andriej Rublow Andrieja Tarkowskiego, wyprodukowany w 1966 roku i opowiadający o średniowiecznym mnichu i pisarzu ikon przez pryzmat historii walk narodu rosyjskiego $\mathrm{z}$ tatarskim najeźdźcą. Zadanie przedstawienia środowiska i historii „dalekiego kraju”, który wydał papieża, Zanussi powierzył kolejnym mistrzom: eseiście i pisarzowi Janowi Józefowi Szczepańskiemu i - przede wszystkim - felietoniście Andrzejowi Kijowskiemu, pamiętającemu Wojtyłę jeszcze z czasów jego posługi w kościele św. Floriana w Krakowie. „Zgodziłem się na to zanim mnie zapytał o zgodę i zanim się zastanowiłem" - pisał Kijowski w swoim Notesie, pod datą 2 września 1979 roku. I dalej: „Chcę brać udział w tej imprezie i gdyby Zanussi nie zwrócił się do mnie, czułbym się obrażony (...). Chcę poprzez ten film wejść w kontakt z Papieżem (...). Chcę się tym zajmować, bo mnie to - tj. Papież i jego życie - rzeczywiście interesuje". W dalszej części notatki Andrzej Kijowski sugerował, że nikt nie stworzy tej opowieści tak dobrze, jak on. O samym bohaterze pisał zaś - w pewnym sensie - proroczo: „To jest naprawdę ktoś podobny do Jezusa Chrystusa, i o Nim świadczący tak jak świadczyli święci. To jest święty”'

${ }^{3}$ M. Maszewska-Łupiniak, Zanussi Krzysztof, hasło [w:] Encyklopedia kina, wyd. II poszerzone, red. T. Lubelski, Kraków 2010, s. 1076.

${ }^{4}$ K. Zanussi, Pora umierać, Warszawa 1999, s. 159.

${ }^{5}$ A. Kijowski, Notes konwojenta 1955-1985, spisał: A.T. Kijowski, www.kijowski.pl, s. 783785 (dostęp: 10.3.2021). 
Pierwsza wersja scenariusza, zatytułowana Powołanie. Opowieść filmowa o polskim papieżu, mówiła o ojcu św. tak, jak chciał Zanussi - w sposób epicki, ale syntetyczny. Z zapisków Kijowskiego wynika, że współpraca ze Szczepańskim nie układała się jednak najlepiej, i że jego samego nękało wiele wątpliwości związanych ze sposobem przedstawienia na srebrnym ekranie tak wielkiej postaci. 20 listopada 1979 roku Kijowski pisał: „Wczoraj Zanussi. Kazałem mu czytać «scenki» Jana Szczepańskiego. Są żałosne, a on zagubiony kompletnie”6. I dalej, już u progu 1980: „Wczoraj był Szczepański. Dlaczego czuję się z nim źle? (...) Zdaje się, że mi z nim po prostu okropnie nudno i że tę nudę odczuwam jako winę wobec niego"7. Szczepański nie pozostawał Kijowskiemu dłużny, zarzucając mu konstruowanie sentencjonalnych dialogów i kreowanie postaci komunistów w sposób hamletyczny. Obawy związane z samym pomysłem nakręcenia filmu o żyjącym papieżu nękały twórców już od początku współpracy, o czym świadczy jeden z pierwszych wpisów Kijowskiego na ten temat, datowany na 16 sierpnia 1979 roku:

Jak napisać scenariusz? Nie wiem. Ma to być rzecz o Papieżu tak napisana, aby On sam w tym nie wystąpił; wymyśliłem coś w rodzaju „biografii równoległej”, tzn. zamierzam opowiedzieć historię człowieka, który Karola Wojtyły nie zna, i nigdy go właściwie nie spotkał, ale którego życie zawiera wszystkie te same składniki, składa się z tych samych wątków, przebiegało przez te same „katarakty”; jest to więc człowiek, który o Wojtyle wie wszystko nigdy z nim nie rozmawiając, i którego los raz po raz przecinał los samego Wojtyły. Mój bohater jest inny, ale tak samo jak Wojtyła „uwarunkowany”; co więcej życie Wojtyły stało się, czy też było, zawsze osobliwym kryterium jego życia. Jest to po prostu kryterium świętości ${ }^{8}$.

Sytuacja Kijowskiego jako scenarzysty była szczególna. W latach 40. przyszły literat mieszkał przy ulicy Warszawskiej w Krakowie w kamienicy przylegającej do wikarówki kościoła św. Floriana, który był dla niego świątynią dzieciństwa, dojrzewania, wczesnego przeżywania religii i wiary. „Ten Kościół obumarł dla mnie właśnie wtedy, kiedy w nim zjawił się Karol Wojtyła”" - pisał Kijowski, tonem oskarżenia, w liście do asystenta kościelnego „Tygodnika Powszechnego”, księdza Andrzeja Bardeckiego. Wojtyła był stałym spowiednikiem jego matki, a dla niego samego - pewnego rodzaju wyrzutem sumienia i jednocześnie mędrcem, który przemawiał z ambony w sposób literacki, humanistyczny, a zatem niezwykle bliski. Kijowski porzucił wiarę dla literatury, Wojtyła odwrotnie - odstąpił częściowo

\footnotetext{
${ }^{6}$ A. Kijowski, Notes konwojenta..., dz. cyt., s. 867.

${ }^{7}$ A. Kijowski, Notes konwojenta..., dz. cyt., s. 891.

${ }^{8}$ A. Kijowski, Notes konwojenta..., dz. cyt., s. 773-774.

${ }^{9}$ A. Kijowski, Notes konwojenta..., dz. cyt., s. 928.
} 
od sztuki dla wiary, stając się kimś, kim późniejszy autor Kronik Dedala chciał pierwotnie być. „To dziecko wielu łez” - mówił o młodym Andrzeju, za świętym Augustynem, przyszły papież. Słowa te docierały do adresata niejako zza kadru, za pośrednictwem matki. Tak też Kijowski postanowił skonstruować opowieść o papieżu, mówiącym do widza w sposób pośredni i nieoczywisty, z pomocą bohatera „równoległego i tak jak Wojtyła uwarunkowanego”, w rzeczywistości zaś stanowiącego alter ego samego autora. Bohaterem tym był pisarz, Tadeusz Sobański (mistrzowska rola brytyjskiego aktora Christophera de Lerissona Cazenove'a, fizycznie podobnego do polskiego scenarzysty), zaś potwierdzenie tezy, iż jest to opowieść o samym Kijowskim, znajduje się w jego zapiskach. 17 września 1979 roku felietonista „Tygodnika Powszechnego" zanotował bowiem uwagę następującą: „Pisanie noweli o papieżu. Właściwie o sobie. Jestem w momencie newralgicznym. Czuję, że mi się ta opowieść z serca wylewa, ale i tak jest niezdarna..."10

\section{Biografia równoległa}

Czym więc jest pierwszy w historii kinematografii film o żyjącym papieżu, poza osobistym rozliczeniem Andrzeja Kijowskiego z własnym, niespokojnym i nadwerężonym, sumieniem? Wiesława Tomaszewska, w eseju opisującym literacką postawę Kijowskiego wobec myśli Karola Wojtyły zauważa, że scenariusz $Z$ dalekiego kraju jest czymś więcej, niż tylko „biografią równoległą”. „Film ten jest bowiem - wyjąwszy kilka epizodów - rzeczą autobiograficzną o Andrzeju Kijowskim jako postaci indywidualnej, silnie związanej ze środowiskiem pisarskim"11 - pisze Tomaszewska, zwracając jednocześnie uwagę na fakt, iż wszelkie „papieskie” narracje tego autora oscylują wokół opisów sytuacji poznawczej i paradygmatu ludzkiego doświadczenia rozumianego na dwa sposoby: dotknięcia własnego „ja” i poznania drugiego człowieka (co jest bezpośrednim nawiązaniem do myśli Karola Wojtyły wyrażonej w antropologicznych studiach Osoba i czyn z 1969 roku). Sam Kijowski mówił z kolei o pomyśle Zanussiego jako o dramacie ideologicznym $^{12}$, którego sensem jest nie tyle poznanie bohatera, ile idei i poglądów reprezentowanych przez niego w życiu oraz na ekranie. A zatem $Z$ dalekiego kraju nie jest filmem biograficznym ani klasyczną fabułą opowiadającą o życiowej drodze Karola Wojtyły. Nie jest także hagiografią, choć pójście tą (zdaniem Zanussiego -

${ }^{10}$ A. Kijowski, Notes konwojenta..., dz. cyt., s. 791.

${ }^{11}$ W. Tomaszewska, Andrzej Kijowski wobec Karola Wojtyły - Jana Pawła II: tekstowy obraz doświadczenia osoby, Zeszyty Naukowe „Scripta Humana”: Kultura nie tylko literacka. W kręgu myśli Karola Wojtyły - Jana Pawła II (2018) cz. 2, s. 228.

${ }^{12}$ A. Kijowski, Notes konwojenta..., dz. cyt., s. 862. 
wysoce nietaktowną ${ }^{13}$ ) drogą z pewnością przyczyniłoby się do jego komercyjnego sukcesu. Jest za to opowieścią o dwudziestowiecznej Polsce, której historia splata się z losami nowego biskupa Rzymu, i której główny bohater paradoksalnie pozostaje postacią drugoplanową, równie odległą dla widza, co kraj, z którego pochodzi. I tylko na taki rodzaj narracji Jan Paweł II wyraził zgodę podczas spotkania z Zanussim, Szczepańskim i Kijowskim, do którego doszło 13 marca 1980 roku w Watykanie. „Powiedział, że tak jak jest, tzn. że postać papieża zostanie ukryta, jest dobrze. Że nie zgodziłby się na film biograficzny za życia” - notował Andrzej Kijowski w dzienniku. Była to jednak zgoda pozorna, niejako wymuszona, o czym ojciec św. poinformował twórców filmu wprost: „Kiedy papież ma mianować biskupem jezuitę, pyta go o zgodę, ten musi odmówić. Potem papież zwraca się do generała. Generał też odmawia. Ale wiadomo, że kiedy papież ostatecznie jezuitę mianuje, ten przyjmie... Więc ja też tak się nie zgadzam, a wy i tak zrobicie"14.

$Z$ punktu widzenia warsztatu filmowego $Z$ dalekiego kraju wymyka się utartym konwencjom i nie pozwala się zakwalifikować ani do nurtu fabuł dokumentalizowanych, ani do obszaru dokumentów fabularyzowanych. Narracja prowadzona przez Zanussiego ma kształt kontrapunktyczny, nawet hybrydowy - zawiera elementy fabularnej biografii filmowej skonfrontowane z piętnastoma fragmentami dokumentalnymi z udziałem lektora. Trudno ocenić, która z zaproponowanych formuł pełni tu kluczową rolę - fabuła opisująca „biografię równoległą” czy dokument przedstawiający kronikę „dalekiego kraju” i pokazujący prawdziwą postać papieża. Z pewnością panorama losów narodu polskiego ukazana jest w sposób niezwykle epicki, pod pretekstem biograficznej opowieści o wielkim człowieku stale obecnym w tle. Tego rodzaju zabawa $\mathrm{z}$ widzem stanowi wizytówkę twórczości filmowej Krzysztofa Zanussiego, dla którego wyjście poza tradycję gatunku jest stałym elementem warsztatu. Wystarczy wspomnieć pierwszą pełnometrażową fabułę - Strukturę kryształu z 1969 roku - w której reżyser, zainspirowany Żywotem Mateusza Stanisława Leszczyńskiego, próbował dostosować akcję do naszkicowanej wcześniej muzyki (skomponowanej najpierw przez Henryka Mikołaja Góreckiego, potem przez Wojciecha Kilara). Innym, bodaj najbardziej transparentnym przykładem fuzji gatunków filmowych jest Iluminacja z roku 1972, będąca niejako autorskim wykładem reżysera wygłoszonym w postaci hybrydowego zapisu łączącego cztery typy wypowiedzi: fabuły kinowej, dokumentu, filmu edukacyjnego i traktatu filozoficznego. Aktywność Zanussiego w kinie jest bowiem tożsama z eksperymentem w zakresie formy filmowego dzieła.

Hybrydowa konstrukcja dramatu o papieżu Polaku ma określony cel: pomaga odbiorcy zorientować się w zawiłościach i faktach historycznych dwudziestowiecznej

${ }^{13}$ K. Zanussi, Pora umierać, dz. cyt., s. 159.

${ }^{14}$ A. Kijowski, Notes konwojenta..., dz. cyt., s. 914-915. 
Polski. Mariola Marczak dodaje, że „przerywanie akcji filmu faktograficznymi informacjami służy uzupełnianiu nieobecności głównego bohatera w sferze wizualnej" ${ }^{15}$. W scenach fabularnych Karol Wojtyła pojawia się bowiem zaledwie kilkukrotnie, i w żadnej z nich nie zostaje ukazany w sposób transparentny. Po raz pierwszy widzimy go w czołówce, jako kilkuletniego chłopca uczestniczącego w inscenizowanej drodze krzyżowej w Kalwarii Zebrzydowskiej, w 1926 roku. Tu postać małego Karola ukazana jest najwyraźniej, a sama sekwencja ma wydźwięk symboliczny, podszyty nutką ironii. Chłopiec obserwuje bowiem misterium, a gdy po skończonej uroczystości traci z oczu ojca, zauważa ze zgrozą odtwórcę Jezusa (Kazimierz Borowiec) pijącego w karczmie piwo. Marek Lis, w artykule opisującym film Zanussiego, posługując się kluczem biblijnym dostrzega w tym zdarzeniu czytelną „niezgodę na profanację, wyrażoną gwałtownie przez Jezusa, wyrzucającego handlarzy z jerozolimskiej świątyni (Łk 19, 45-46)"16.

Siedmiominutowa sekwencja czołowa sugeruje z pozoru, że dalsza część opowieści będzie ujęta $w$ formułę klasycznej biografii filmowej. Staje się jednak inaczej w kolejnych ujęciach postać dorosłego Wojtyły (w tej roli Cezary Morawski) jedynie miga widzowi przed oczami, lub ukazuje się w pozach utrudniających identyfikację jego personaliów. Jak bowiem pisał Kijowski, „w opowieści o bohaterze trzeba wyraźnie odróżnić porządki: historyczny i mitologiczny - dwie struktury: strukturę historyczną postaci, która podlega ocenie i strukturę bohatera, która podlega interpretacji” ${ }^{17}$. Ta interpretacja w scenach fabularnych $Z$ dalekiego kraju jest celowo utrudniona, dzięki Idziakowi filmującemu postać Wojtyły w dalekich planach lub w zbliżeniach ukrywających twarz. I tak w scenie mszy prymicyjnej kamera przedstawia Cezarego Morawskiego leżącego krzyżem, po czym następuje jej odejście $\mathrm{w}$ celu oddalenia postaci od widza (podobne ujęcie ma miejsce w chwili, w której Wojtyła dowiaduje się o otrzymaniu godności biskupiej). Spotkanie z kardynałem Sapiehą na korytarzu kurii krakowskiej ujęte jest również z dystansu, a sam Wojtyła ustawiony zostaje tyłem do odbiorcy. W kolejnych ujęciach twarz Cezarego Morawskiego skrywa się w konfesjonale, za krzyżem ustawionym na ołtarzu katedry wawelskiej lub w dalekiej perspektywie, skąd widziana jest oczami tłumu (tak dzieje się na przykład w scenie mszy św. celebrowanej przez Wojtyłę w prowizorycznej kaplicy w Nowej Hucie, kiedy padają płomienne słowa: „Popatrz Chryste, jakżeś się wzbogacił"). Idziak operuje także detalem, robi to jednak w sposób nader osobliwy: w ujęciu udzielania komunii filmuje dłonie przyszłego papieża, ukazując jednocze-

${ }^{15}$ M. Marczak, Niepokój i tęsknota. Kino wobec wartości. O filmach Krzysztofa Zanussiego, Olsztyn 2011, s. 268.

${ }^{16}$ M. Lis, $Z$ dalekiego kraju. Karol Wojtyła widziany z daleka, „Media-kultura-komunikacja społeczna" (2016) nr 12/2, s. 39. sków).

${ }^{17}$ A. Kijowski, Notes konwojenta..., dz. cyt., s. 903 (podkreślenie pochodzi od autora zapi- 
śnie bardzo wyraźnie twarze osób przyjmujących Eucharystię. Wszystko to dzieje się po to, by - jak zauważa Marek Lis - „w pamięci widza utrwalała się twarz prawdziwego Karola Wojtyły, rozpoznawalnego na archiwalnych fotografiach"18. Jest rzeczą znamienną, że pełną sylwetkę Jana Pawła II obserwujemy dopiero w dniu jego wyboru na Stolicę Piotrową, w dokumentalnym ujęciu ogłoszenia decyzji konklawe. Wkrótce następuje wzniosły, pełen nadziei finał z uroczystą mszą św. na Błoniach, $\mathrm{w}$ archiwalnej odsłonie $\mathrm{z}$ wizerunkiem papieża zatrzymanym w kadrze.

\section{Przestrzeń ekranowa}

Narracja $Z$ dalekiego kraju ujęta jest zatem w ramę, prezentującą obraz polskiego Kościoła w perspektywie półwiecza (od lat 20. do 70.). Fabularyzowane misterium pasyjne otwierające film odbywa się w śniegu i mrozie, zaś finałowy dokument przedstawiający tłumy wiernych i mszę na Błoniach - w słońcu. Marek Lis puentuje:

Zima ustępuje miejsca słonecznej pogodzie, pasyjny spektakl - autentycznemu triumfowi, aktorsko odtwarzane postaci - rzeczywistej postaci papieża, widzialnej głowy Kościoła. Motyw spełniających się nadziei był na początku lat osiemdziesiątych bardzo potrzebny polskiej publiczności ${ }^{19}$.

Historia narodu polskiego, podobnie jak osoba Karola Wojtyły, ukazana została przez reżysera w dwóch obszarach przestrzeni filmowej: w kadrze i zza kadru. Osią narracji widocznej na ekranie Zanussi uczynił pięć obszarów historycznych (a jednocześnie pięć lokacji czasowych), definiujących dzieje dwudziestowiecznej Polski od czasów drugiej wojny światowej po dekadę gierkowską. To właśnie na ich tle toczy się życie środowisk i ludzi z otoczenia przyszłego papieża. Perspektywa historyczna kraju wychowującego Karola Wojtyłę przedstawia się w sposób następujący:

\section{Rzeczywistość wo je n na.}

Zanussi rozpoczyna opowieść o Polsce mocnym akcentem związanym z obozem koncentracyjnym w Auschwitz. To doskonały moment, aby przypomnieć zagranicznemu odbiorcy historię beatyfikowanego (wkrótce - już za sprawą Jana

${ }^{18}$ M. Lis, $Z$ dalekiego kraju..., dz. cyt., s. 39.
${ }^{19}$ M. Lis, $Z$ dalekiego kraju..., dz. cyt., s. 38. 
Pawła II - kanonizowanego) męczennika, Maksymiliana Marię Kolbego. Bohaterstwo franciszkanina ukazane jest tu w formie epizodu, dziesięć lat później doczeka się jednak pełnometrażowego ujęcia w filmie Życie za życie. Maksymilian Kolbe Krzysztofa Zanussiego. Pozostałe elementy rzeczywistości wojennej, które przedstawiają obraz ojczyzny Jana Pawła II „obcemu” odbiorcy, to przede wszystkim widmo getta i system konspiracyjnej edukacji, kultury i sztuki w czasach okupacji (tajne komplety, teatr konspiracyjny, podziemne seminarium duchowne). Sam Karol Wojtyła, chcąc uniknąć wywózki do Niemiec, zatrudnia się jako robotnik w zakładach chemicznych Solvay. O tym, kim jest, a także o wypadku, któremu uległ w fabryce, dowiadujemy się wyłącznie z warstwy słownej dramatu („Tak, to [teczka] Karola, on ciągle teologię czyta" ${ }^{20}$ ). Od tego momentu fabuła koncentruje się na „biografii równoległej” i losach kilkorga młodych Polaków: aktorki Wandy (Liza Harrow), jej brata Mariana, który wkrótce - podobnie jak Karol - otrzyma święcenia kapłańskie (Sam Neill), robotnika Władka będącego synem odtwórcy roli Jezusa w misterium pasyjnym z filmowej czołówki (Warren Clarke) i wspomnianego wcześniej Tadeusza Sobańskiego, niebawem pisarza socrealistycznego (Christopher de Lerisson Cazanove).

\section{Rzeczywistość powo je n na.}

Na oczach widza rodzi się Polska Rzeczpospolita Ludowa. Z ust Wandy słyszymy, że „Karol już nie gra [w teatrze], uczy się na księdza w tajemnicy”. Kronika dokumentalna informuje o sposobach tworzenia komunistycznego rządu, którego istotnym narzędziem jest budząca grozę służba bezpieczeństwa. Kardynał Sapieha przyspiesza święcenia Karola i wysyła go w podróż do Francji i Belgii. Z archiwów telewizyjnych dowiadujemy się o jego pracy nad dramatem Brat naszego Boga, opisującym życie i dzieło Brata Alberta Chmielowskiego (film oparty na sztuce Wojtyły Zanussi nakręci w 1997 roku). Realia polityczne „dalekiego kraju” oscylują wokół dwóch wydarzeń: ogłoszenia doktryny socrealistycznej w sztuce (Wanda, słysząc słowa „Albo teatr realizmu socjalistycznego albo brak teatru”, rezygnuje z kariery scenicznej) oraz budowy Nowej Huty jako pierwszego socjalistycznego „miasta”.

\section{Rzeczywistość stalinowska.}

Nadchodzi era posługi „Wujka” w parafii św. Floriana w Krakowie, o czym informuje odbiorcę kolejny fragment kroniki filmowej. Akcja nabiera tempa - umie-

${ }^{20}$ Cytaty filmowe podaję za materiałem audiowizualnym. 
ra Józef Stalin, w kraju trwają zamieszki, a poznany wcześniej żydowski uciekinier z getta (pełniący funkcję oficera SB) oddaje legitymację partyjną tłumacząc widzowi, że „są rzeczy ważniejsze niż sukces”. Wanda, początkowo niechętna wierzącemu w socjalizm Tadkowi, ostatecznie zgadza się zostać jego żoną. To ważny moment, w którym w sposób transparentny ujawnia się alter ego Andrzeja Kijowskiego. We wstrząsającej scenie spowiedzi ( $\mathrm{z}$ „Wujkiem” ukrytym za kratą konfesjonału) Sobański/Kijowski przyznaje bowiem światu, że nie wierzy. „Ale w co nie wierzysz?” - pada zaskakujące pytanie, z którego wyłania się wkrótce myśl Karola Wojtyły oscylująca wokół słów: „W języku teologii serce znaczy człowiek”.

\section{Rzeczywistość po politycznej „o d wil ży”.}

I oto nastaje rok 1956, od którego „zacząłem zauważać różnice między teorią a praktyką” - jak informuje widza były oficer SB. Wojtyła zostaje biskupem „podczas spływu kajakiem", o czym dowiadujemy się z ust siostry zakonnej. Jego życie coraz silniej wsiąka w realia polityczne kraju - rozpoczyna się batalia o budowę kościoła i ustawienie krzyża w Nowej Hucie, a podczas Soboru Watykańskiego II w 1962 roku biskup Wojtyła otrzymuje w Rzymie kamień pod fundamenty nowej świątyni. W roku 1968 przychodzi załamanie - wydarzenia marcowe rozpoczynają krwawe represje i bezwzględną nagonkę na Żydów. Nadzieja rozbudzona październikową odwilżą 1956 roku umiera.

\section{Rzeczywistość dekady g i e rk o ws ki e j.}

Lata 70. XX wieku; Karol Wojtyła zostaje kardynałem. Zanussi ukazuje go widzowi $z$ daleka podczas prowadzenia nauk, i to od niego dowiadujemy się, że „Wawel to katedra, w której skupia się historia polskiego narodu”. Kluczowe wydarzenia tego okresu ukazane zostają w archiwalnej odsłonie - lektor informuje widza o beatyfikacji Maksymiliana Marii Kolbego w 1971 roku, odejściu Pawła VI i zaskakującej śmierci Jana Pawła I po trzydziestu trzech dniach pontyfikatu. Moment kulminacyjny filmu - konklawe w 1978 roku - przyjmuje hybrydową postać dokumentu podbarwionego fabułą. Wybór Wojtyły na tron Piotrowy budzi u jego przyjaciół euforię, ale także niepokój o dalszą posługę i los. „Czy oni zrozumieją to, przez co przeszedł?” - pyta Tadeusz Sobański, zdradzając po raz kolejny, iż jego postać to porte-parole Andrzeja Kijowskiego. W zapiskach scenarzysty znajdują się bowiem wpisy zdradzające jego obawy związane z objęciem przez Polaka najwyższej godności kościelnej. „Chyba nigdy nie byłem tak szczęśliwy. To znaczy 
wiedziałem, że jestem szczęśliwy, a czułem się fatalnie"21 - notował Kijowski 28 października 1978 roku. I wreszcie finałowa scena pierwszej pielgrzymki Jana Pawła II do Polski, w czerwcu 1979 roku - z tłumem wiernych na Błoniach, zwycięstwem nadziei, triumfem wiary i prawdy nad krzywdą, niewolą i presją. „Daleki kraj” - za pośrednictwem narracji filmowej - przeszedł społeczną, mentalną i historyczną metamorfozę.

Ta swoista lekcja historii, której Zanussi (świadomie stawiając się w roli mentora) udziela zagranicznemu widzowi, toczy się w rzeczywistych miejscach splecionych z losami papieża. Marek Lis pisze:

W przeciwieństwie do późniejszych filmów plenery tego obrazu są autentyczne Rzym jest Rzymem, Kraków - Krakowem (może poza budową Nowej Huty, filmowaną pod krakowskimi Bielanami, rozpoznawalnymi dzięki charakterystycznemu kościołowi kamedułów na wzgórzu) $)^{22}$.

Wydarzenia historyczne oglądane w kadrze wysuwają się zatem na pierwszy plan, sprowadzając postać Karola Wojtyły do roli komentarza, tła, pretekstu do opowiedzenia historii o Polsce. Jednak tylko z pozoru.

\section{Przestrzeń pozakadrowa}

Specyfika intertekstualnego dzieła sztuki, jakim jest film, stwarza dla reżysera możliwość przemówienia do widza wielodialektowym językiem. To, co odbiorca widzi na ekranie, stanowi jedynie część narracji filmowej, której znaczenia i sensy lokowane są w różnych przestrzeniach utworu. Film, jak chciał Roman Ingarden, jest dziełem warstwowym, widowiskiem szczególnie złożonym o skomplikowanej budowie, „odznaczającym się wielogłosowością (polifonią) współwystępujących i współgrających ze sobą czynników, których obecność w jednej całości prowadzi do pojawienia się zjawisk różnego typu zestrojów (harmonii) i rozstrojów (dysharmonii)"23. Owe warstwy dzielą się (w uproszczeniu) na obraz, słowo, dźwięk. Warstwa pierwsza, ściśle związana z kadrem, ma wartość poznawczą i jest głównym nośnikiem treści filmowego dzieła. Warstwa druga, stojąca niejako pomiędzy ekranem a przestrzenią pozawizualną (ale nie pozafilmową!), pełni rolę informacyjną, dopełniając sobą to, co pokazuje kadr. I wreszcie warstwa trzecia,

${ }^{21}$ A. Kijowski, Notes konwojenta..., dz. cyt., s. 701.

${ }^{22}$ M. Lis, $Z$ dalekiego kraju..., dz. cyt., s. 39.

${ }^{23}$ R. Ingarden, Kilka uwag o sztuce filmowej, [w]: Studia z estetyki, t. 2, Warszawa 1966, s. 315 . 
ulokowana wewnątrz ekranu lub poza nim, posiada charakter stricte estetyczny i stanowi metaforyczne narzędzie zdolne do odkrywania znaczeń i myśli niewidocznych w obrazie. Tak też dzieje się w wypadku pierwszej pełnometrażowej fabuły o papieżu Polaku.

Skomponowanie muzyki do $Z$ dalekiego kraju Zanussi powierzył Wojciechowi Kilarowi, z którym współpracował od czasów eksperymentalnej Struktury kryształu z 1969 roku. O sferze dźwiękowej zmieniającej i wartościującej wagę wydarzeń ukazanych na ekranie, a także takiej, która odnajduje bądź uwypukla treści pominięte w obrazie i słowie reżyser mówił, że jest „semantycznym rodzajem interpretacji, która ma miejsce wtedy, gdy muzyka wchodzi na piętro dialogu scenariuszowego i wartościuje sens tego, co pokazano" ${ }^{24}$. Na takie właśnie interpretacje Kilar decydował się podczas współpracy z Zanussim.

Ścieżka dźwiękowa do dramatu o Janie Pawle II reprezentuje trzeci, niezwykle intensywny okres twórczości filmowej kompozytora, w którym nie tylko ugruntowuje on swoją estetykę filmowo-muzyczną opartą na postromantycznej symfonice, ale i naznacza ją rodzimym i patriotycznym piętnem. Partytury Kilara z tego okresu (1977-1990) napisane są w duchu amerykańskiej Classical Hollywood Film Score, której charakter staje się jednak na wskroś słowiański. Dzieje się tak przede wszystkim za pośrednictwem tańców polskich wykorzystywanych w muzyce (Kilar chętnie odwoływał się do rytmiki poloneza oraz tańców regionalnych, takich jak kujawiak, oberek, mazur czy krakowiak), ale także dzięki muzycznym cytatom z pieśni oraz hymnów polskich wplatanym w narrację. I tak $Z$ dalekiego kraju rozpoczyna się symfonicznym opracowaniem Bogurodzicy, z którego Kilar wysnuwa kolejne tematy. To z pewnością jedna z najciekawszych czołówek filmowych jego autorstwa - motywy Bogurodzicy potraktowane zostały tutaj jako materiał do dialogu z tematami bardziej współczesnymi. W połączeniu z dramatyczną sekwencją drogi krzyżowej w Kalwarii i mistrzowskimi zdjęciami Sławomira Idziaka, pierwsze siedem minut filmu stanowi przejmujący obraz udręczonej wojnami Polski, zarówno tymi, które przeszły, jak i tą, która miała dopiero nastąpić. Oryginalny cytat hymnu - w symfonicznym unisono - pojawia się tu dwukrotnie: na początku oraz w finale pasyjnego misterium. Ma on jeszcze jedną, niezwykle istotną funkcję - podpowiada widzowi, że to właśnie Karol będzie głównym bohaterem dramatu. Przypominając Bogurodzicę w kluczowych scenach opisujących Wojtyłę (przyjęcie święceń kapłańskich, walka o krzyż w Nowej Hucie, kiedy jedna z dziewcząt wypowiada słowa: „To wuj nam powiedział...”) twórcy filmu stawiają jego osobę - w sposób nieoczywisty, wbrew zapowiedziom i w pewnym sensie w sprzeczności z obrazem - na najważniejszej pozycji. Innymi

${ }^{24}$ M. Malatyńska, A. Malatyńska-Stankiewicz, Scherzo dla Wojciecha Kilara, Kraków 2002, s. 39. 
słowy: Bogurodzica symbolizuje Polskę. Polska zaś pozostaje organicznie związana z osobą przyszłego papieża.

W partyturze Kilara znajdują się jeszcze dwie myśli muzyczne, które - podobnie jak monumentalna uwertura, ale z mniejszą siłą - ustalają wagę opisywanych wydarzeń. Plenerom ojczyzny powracającej do życia po okupacyjnym piekle towarzyszy skromna melodia oboju solo, o melancholijnym, pełnym refleksji wydźwięku. Jest to niewątpliwie temat filmowy o najmniejszej nośności, a jego zadanie polega w dużej mierze na dźwiękowej ilustracji krajobrazu Polski udręczonej wojną. Większe znaczenie reżyser przypisuje scenom związanym z Kościołem i jego historią - ujęciom przedstawiającym beatyfikację Maksymiliana Marii Kolbego czy przywołującym wspomnienie Wojtyły o kardynale Adamie Sapiesze towarzyszy wzniosła kantylena skrzypiec na tle kroczącego basu, skomponowana w duchu Bacha i Albinoniego i nawiązująca charakterem oraz motywiką do słynnej arii przeznaczenia z Iluminacji Krzysztofa Zanussiego. Temat ten brzmi także we fragmentach dokumentalnych opisujących konklawe z 1978 roku oraz pierwszą pielgrzymkę Jana Pawła II do Polski, zrealizowaną rok później. Znak, że Karol Wojtyła jest już częścią historii Kościoła i świata, a nie tylko ziemi ojczystej.

\section{Glosa na zakończenie}

$Z$ dalekiego kraju nie jest zatem filmem wyłącznie o Polsce, lecz raczej transparentnym dowodem na to, iż jej historia pozostaje spójna i nierozerwalna z losami, postawą i myślą Karola Wojtyły. Pierwsza pełnometrażowa opowieść o głowie Kościoła ${ }^{25}$ znalazła wkrótce dopełnienie we włoskim dokumencie Zanussi racconta Wojtyła, wyreżyserowanym przez Carla Mazzarellę i Leonarda Valente w 1981 roku, a już w nowym millennium - w etiudzie Czołgi pochodzącej z noweli Solidarność, Solidarność..., skonstruowanej przez kilku reżyserów w 2005. Zanussi, jako przedstawiciel kina Młodej Kultury, dołożył wszelkich starań, aby uniknąć stereotypów poznawczych usypiających czujność i ograniczających percepcję odbiorcy. Hybrydowa konstrukcja dramatu miała wymiar dydaktyczny, było to jednak działanie celowe (wszak kino Młodej Kultury skupiało się również na formie, a jego głównym hasłem stało się „mówienie wprost”), reżyser bowiem musiał „liczyć się z widzem niemającym pojęcia, czym jest Polska, co to za kraj,

${ }^{25}$ Wcześniej, w 1979 roku, Andrzej Trzos-Rastawiecki nakręcił film dokumentalny Pielgrzym, będący zapisem pierwszej pielgrzymki Ojca Świętego do Polski i jednocześnie pierwszą produkcją zrealizowaną w PRL na zlecenie Kościoła; obecnie w dorobku kinematografii światowej znajduje się blisko 200 utworów filmowych (dokumentalnych, fabularnych, krótko - i pełnometrażowych) opisujących sylwetkę i kulisy pontyfikatu Jana Pawła II. 
jaka historia za nią stoi, jaki jest związek polskości z katolicyzmem"26. Co za tym idzie, nie mógł pozwolić sobie na niedopowiedzenia, skojarzenia czy poetycką symbolikę niezrozumiałą dla zagranicznego widza. Już jednak sama historia papieża, ukryta częściowo poza ekranem i niepodawana na tacy, wymyka się wcześniejszym konwencjom i staje u progu ,intelektualnych tendencji”, tak chętnie realizowanych przez Zanussiego w kinie. „Biografia równoległa” stworzona przez Kijowskiego i Szczepańskiego zmusza do myślenia. Lwia część narracji ukryta za kadrem uruchamia kreatywność widza. Jak bowiem chciał Grzegorz Królikiewicz: „Artysta musi odbiorcę zaskakiwać, niepokoić; w kinie najlepszym wiodącym do tego środkiem jest «inscenizacja demokratyczna», stosująca relatywizm akcentów i zmuszająca widza do uruchamiania wyobraźni”27.

\section{Abstract \\ From a far country. The thought of Karol Wojtyła in the film frame and from behind film frame.}

The Polish-British-Italian production From a far country directed by Krzysztof Zanussi (1981) is a special work that eludes screen conventions both in terms of the workshop (a kind of a hybrid of a plot movie and a documentary) and aesthetics. The screenplay by Andrzej Kijowski and Józef Szczepański is not so much a biographical as a historical one, and its main goal is to familiarize the viewer with the history of ,the distant (and at the same time, due to Christian traditions, so close) country", from which the Pope comes. The character of Karol Wojtyła (Andrzej Kijowski's alter ego in the film) is presented provocatively - at times we can see him from a distance, with his back turned, or we can't see him at all. According to cinematic historians, the phenomenon of the first story about John Paul II consists precisely in the fact that it is a film about the Pope without... the Pope. In reality, however, this is an apparent impression, and the protagonist of the story is constantly present in the film, through non-frame elements of the film language, especially music (Wojciech Kilar). From a far country us, therefore, not only a film about Poland, but rather a transparent proof that is history remains coherent and inseparable from the fate, attitude and thought of Karol Wojtyła.

Keywords: Jan Paweł II, Karol Wojtyła, Krzysztof Zanussi, Andrzej Kijowski, From a far country, film music

${ }^{26}$ K. Zanussi, www.pallotti.tv (dostęp: 15.3.2021).

${ }^{27}$ G. Królikiewicz, Przestrzeń filmowa poza kadrem, „Kino” (1972) nr 11, s. 25-28, [w]: T. Lubelski, Historia kina polskiego. Twórcy, filmy, konteksty, Chorzów 2008, s. 317. 